\title{
Critical geographies of citizenship and belonging in Ireland
}

\author{
Allen White ${ }^{\mathrm{a}}$, Mary Gilmartin ${ }^{\mathrm{b}, *}$ \\ a University College Cork, Ireland \\ b National University of Ireland, Maynoooth, Ireland
}

\section{A R T I C L E I N F O}

\section{Introduction}

I am Ireland / and I'm silenced.

I cannot tell my abortions / my divorces / my years of slavery /

My fights for freedom.

It's got to the stage where I can hardly remember what I had to tell /

And when I do / I speak in whispers (Medbh, 1993).

Máighréad Medbh's powerful poem, Easter 1991, encapsulates the struggles over the relationship between gender, national identity and Ireland. Medbh's cry - for recognition, for conversation, for openness - is framed in the context of a discursive construction of Ireland that is gendered and exclusionary. This gendered and exclusionary construction of Ireland and Irish identity has been commented on and written about by a range of feminist scholars. Their concerns have included the Irish Constitution, employment rights, reproductive rights, sexuality and mobility, with a particular focus on the restrictions and limitations placed on women

\footnotetext{
* Corresponding author. Department of Geography, National University of Ireland, Maynooth, Co. Kildore, Ireland.
}

(see, for example, Connolly, 2003; Connolly \& O'Toole, 2005; Cullen-Owens, 2005; Hayes \& Urquhart, 2004; O'Connor, 1998; Ryan \& Ward, 2004; Smyth, 1988; Valiulis \& O'Dowd, 1997; Ward, 1991). In this way, discussions about the relationship between gender, national identity and Ireland have paralleled broader international debates around these relationships (see, for example, Anthias and Yuval-Davis, 1989; McClintock, Mufti, \& Shohat, 1997; Yuval-Davis, 1997). More recently, feminist scholars have pointed out the ongoing gendered construction of Irish identity in the face of changing patterns of migration. This work has particularly focused on asylum seekers (see, for example, Lentin, 2003, 2005; Luibhéid, 2004, 2006), with a growing emphasis on pregnant women and on race (see, for example, Fletcher, 2005; Garner, $2005,2007)$. Many of these debates crystallise around the 2004 Citizenship Referendum, which fundamentally changed the basis on which Irish citizenship is granted.

Our article builds on this extensive body of work to argue that recent transformations in the construction of Irish citizenship are best understood as an outcome of complex socio-spatial processes that rely on legally articulated understandings of the relationship between people and place that are both particular and restrictive. We argue that a variety of interconnected spaces, sites and practices are crucial to understanding the ways in which citizenship laws are enacted, enforced and challenged. Our efforts to outline and interrogate these understandings - drawing on critical geographies of the law, scale and mobility - also highlight the 
ways in which these attempts at bounding and separation may be challenged. In short, while our article builds on the case study of Ireland, our analysis has relevance for a variety of instances where law and legal discourse is used as a means to link identity to space and to create geographies of belonging and exclusion.

Our article thus has two parts. The first discusses Ireland and citizenship, and analyses the ways in which the legal discourses that are central to the construction of Irish citizenship rely on seemingly static but fundamentally mutable conceptualisations of the space-identity nexus, particularly in relation to the State, the Family and Women. The second draws on the Irish example to make broader claims about critical geographies of citizenship that have resonance at a range of different scales and in a range of different contexts.

\section{Ireland and citizenship}

In the last four years, significant changes have been made to Ireland's laws about citizenship, asylum and immigration. On January 23rd 2003 the Irish Supreme Court ruled that the 'non-national' parents of Irish citizens did not enjoy the right of residency in Ireland. ${ }^{1}$ After this landmark ruling the constitutional guarantees for citizenship as a right of all children born on the island of Ireland were removed following a referendum passed (with $79 \%$ of the vote) on 11th June 2004 (Brennoch, 2004, p. 1). Some (for example Lentin, 2003) have understood these changes as the state's response to claims about 'abusive' asylum claims. Thus the law can be seen as a 'technology of control' of the state. Equally these changes can be seen as the erasure of particular social and civil rights of certain groups (asylum seekers, 'nonnationals', particular children born in Ireland). Without wanting to dismiss either of these claims, we contend that a full understanding of these changes is dependent on an appreciation of the spaces and identities around which legal and political arguments and claims are organized. We focus on two such intersections: that of the Family and the State; and that of the State and 'Women'.

\section{Family matters: redefining the 'Family' to serve the State}

The Family has a privileged position within the Irish State. Article 41 of Bunreacht na hÉireann (henceforth referred to as the Irish Constitution or the Constitution), enacted in 1937, recognised the importance of the family to Irish life. According to Article 41, the 'Family' was recognized as the natural and primary fundamental unit group or Irish society and as a moral institution possessing inalienable and imprescriptable rights antecedent and superior to all positive law. When, over a decade ago, the Fajujonu family was facing deportation from Ireland, they and their legal team turned to Article 41 when making a case to remain legally in the country. ${ }^{2}$ The Fajujonu family - a Nigerian father, a Moroccan mother and their children - had been living illegally in Ireland since 1981. The three children were all Irish citizens on the basis of their birth. The Fajujonus argued that their eldest child, drawing on her rights under Article 41, was entitled to remain in Ireland with her family and therefore her parents could legally stay in Ireland. The case concluded in the Supreme Court in 1990 with a judgment from Mr Justice Finlay that children have a constitutional right to the company, care and parentage of their parents within a family unit (NCCRI, 2004, p.10).

In the Fajujonu ruling, the courts interpreted the law in a way that prioritized the family unit. The rulings saw the family's integrity as worthy of protection and the directive to break up the family (through effective deportation) needed to be justified by the Minister for Justice as being in the interests of the common good and the protection of the State (in NCCRI, 2004, p.10). After the Fajujonu ruling, it became the practice of officials from the Department of Justice to allow residency to parents and families of Irish citizens (this changed with the serving of deportation orders to two families in 2002).

The Fajujonu ruling was issued and implemented in a period when rates of migration to Ireland were low. From the mid 1990s onwards, however, rates of migration to Ireland began to increase significantly. This was most obvious in the case of applications for asylum in Ireland: these rose from 39 in 1992 to a peak of 11,634 in 2002 (Crowley, Gilmartin, \& Kitchin, 2008). In this changing context, public disquiet was regularly expressed over a perceived abuse of the Irish asylum process. In broad terms, it was speculated that many pregnant women were claiming asylum in Ireland, giving birth to their children in Ireland and then applying for citizenship on that basis. $^{3}$ In this changing climate, the Government became increasingly reluctant to grant leave to remain to the parents of Irish born children. In 2001 the Minster for Justice, Equality and Law Reform refused leave to remain to two families with Irish-born children. The decision was appealed and upheld in the High Court, and was eventually heard before the Supreme Court. In a landmark ruling on January 23rd 2003 the Irish Supreme Court ruled, by five votes to two, to reject an appeal against deportation orders served against a Czech Roma couple and Nigerian couple (henceforth known as the L and $\mathrm{O}$ families) who had sought asylum in Ireland, been refused, and had argued that because their children were born in the Republic of Ireland, they were citizens who were constitutionally entitiled to a family life, it followed therefore that all family members were entitled to residency status in Ireland.

The Supreme Court ruling was not unanimous. Five Justices (Keane, Denham, Murray, Hardiman and Geoghegan) rejected the appeal and two (Fennelly and McGuinness) found in favour. The Court's overall rejection of the L and O families' arguments contained significant disagreements over legal principles and interpretations of Fajujonu. In particular, the dissenting rulings rested on different interpretations of the relationship between the Family and the State. These differences are important, because they highlight the ways in which legal discourses attempt to fix the relationship between space and identity, while at the same time highlighting the ways in which that relationship is discursively altered in response to political and social concerns.

\section{Legal discourses and contested relationships}

The five Justices (Hardiman, Keane, Denham, Murray and Geoghegan) who upheld the High Court ruling and deportation orders on the $\mathrm{L}$ and $\mathrm{O}$ families concentrated on the limitations to the rights given to the family in the Constitution. Justice Hardiman, citing Barrington in the High Court in the original Fajujonu ruling, argued that the Constitution does not contemplate the family as existing in isolation but regards 
it as living in a larger community or society in which the State has a role to play as the guardian of the common good (Lobe, 2003, Para. 372). Justice Denham rejected the L and O families' appeal because of the need to prioritise the sovereign rights of the state to control its borders and the mobility of nonnationals crossing its borders. Justice Keane also focused on the incapability of a child to enjoy his or her social and civil rights. If, Keane argued, a child is incapable of enjoying these rights (in comparison to a rational free adult) then these rights cannot be thought of as absolute. ${ }^{4}$ For these (majority) rulings a key point about the Fajujonu ruling was not that it established a legal principle but that the particular circumstances of the case were central to any understanding of the ruling made by the Supreme Court in 1990. All of the majority rulings included arguments that the specific details (or, to borrow Keane's term, the 'factual matrix') were key to the Fajujonu judgement. The empirical aspects of the Fajujonu case (i.e. where they came from and moved to, how long they had been in Ireland, how many children were born in Ireland) were central to the Court's ruling. In addition all of the majority rulings cited Barrington in the original Fajujonu High Court ruling.

The child clearly has a certain right to be in Ireland. She also has the right to the society of her parents. But it does not follow from this that she has a right to the society of her parents in Ireland (Fajujonu, 1987).

In contrast, dissenting judgments from Justices McGuinness and Fennelly suggested that the appeals be allowed and the deportation orders overturned. These judgments agreed with the appellants' arguments that under Irish law the family is the foundational unit of social order and therefore has constitutional rights superior to the laws of the state. Justice Fennelly reasoned that Article 41.1 of Constitution clearly outlined the philosophical basis of role of family in Irish society i.e. that the rightness of the family exists, family life is a part of 'natural justice' and hence all the Constitution does is confirm the existence of and protect these rights. It follows that the rights of family are superior to those of the State. He argued that the language of Article 41 and a series of previous rulings by the Supreme Court (on different issues including disputes over adoptions) consistently argue the primacy of the family unit in these cases (Lobe, 2003, Para. 516). For Justice McGuinness what was important about Fajujonu was that it was consistent with the line of decisions on the constitutional rights of the family which preceded it (Lobe, 2003, Para. 276). McGuinness argued that the parents of both children were exercising their rights to choose on behalf of their child. In both cases the child's welfare rested in the maintenance of the family unit unless there were 'compelling reasons' for this not to be so (Lobe, 2003, Para. 250). For McGuinness and Fennelly, the integrity and maintenance of the asylum and immigration system were not compelling reasons. These judgments prioritised the constitutional rights of the family for Irish citizens. These rulings can be understood as based upon representations of 'the family' as a conceptual and legal space which enjoys particular rights that, although they do not over-ride other rights (most notably the rights of the state to deport non-citizens), must be treated with the utmost seriousness. The rulings that rejected the families' arguments prioritised the integrity of the State over these constitutional rights. These rulings were based upon representations of the nation and the paramount importance of maintaining national borders and sovereignty.

\section{The place of women in the practice of citizenship}

The January 2003 Supreme Court rulings were built upon a series of arguments and claims about specific public (the State) and private (the Family) spaces. The resulting configuration resulted in the exclusion and expulsion of specific kinds of families from Ireland. In the rest of this article we go on to consider the subsequent Citizenship Referendum in June 2004. We argue that the debates surrounding this constitutional referendum derive their meaning in part from ongoing struggles in Ireland over state control over women's reproductive, sexual and mobility rights. This, we argue, is crucial to how the Irish state puts citizenship into practice.

\section{'Citizenship tourism' and the Citizenship Referendum, June 2004}

After the Supreme Court rulings, attention turned to Ireland's citizenship laws, the very 'natural' rights enjoyed by the Fajujonu, L and O children. The 2004 Citizenship Referendum was announced in March 2004 and passed in June 2004 , with $79 \%$ of voters favouring its introduction. The resulting amendment to the Constitution changed the basis for Irish citizenship from birth to blood, and ensured that citizenship would be in the future defined legislatively rather than constitutionally. It read:

Notwithstanding any other provision of this Constitution, a person born in the island of Ireland, which includes its islands and seas, who does not have, at the time of the birth of that person, at least one parent who is an Irish citizen or entitled to be an Irish citizen is not entitled to Irish citizenship or nationality, unless provided for by law (Referendum Commission, 2004).

In this way, the Citizenship Referendum explicitly related Irish citizenship to ancestry and bloodline. This is in contrast to the earlier Supreme Court rulings which, with the exception of Justice Keane, did not discuss the ethnicity of the $\mathrm{L}$ and $\mathrm{O}$ families. ${ }^{5}$ The ethnicity of the $\mathrm{L}$ and $\mathrm{O}$ families Nigerian and Roma - is not insignificant. These groups were numerically greatest in the asylum system, and they were also constructed as problematic within racialised discussions about Irishness in the late 1990s (see Lentin and McVeigh, 2002). Thus while the ethnicity of the $\mathrm{L}$ and $\mathrm{O}$ (and, earlier, the Fajujonu) families were not explicitly made part of the Supreme Court rulings, they structured the political responses, developments and debates in the aftermath of the rulings in such a way as to rule out particular familes from being part of the national family. For some commentators, the results of the referendum represented the negation of the possibility of an Irish multiculturalism, planned and executed by a political elite in Ireland who were themselves conforming to a 'Fortress Europe' (for example see Garner, 2005; Lentin, 2005). As persuasive as this argument is, we suggest that it fails to adequately explore why an abstract notion like citizenship gained such political 'traction' so quickly. We maintain that the Citizenship Referendum and the discourses 
that surrounded it are better understood in the context of 20 years of feminist struggles over reproductive and mobility rights in Ireland. The existence of a reservoir of contradictory claims, anxieties and ambiguities surrounding the politics of abortion rights, mobility rights and the pregnant body in Ireland helped create the conditions for various claims about the Citizenship Referendum to make sense to the Irish electorate.

\section{Problem pregnancies and the threat of mobility}

The reasons given for such a fundamental change to the concept of citizenship in Ireland were, on the surface, straightforward. According to politicians, the 19th amendment to the Constitution, introduced in 1998 and guaranteeing Irish citizenship to anyone born on the island of Ireland, had resulted in an unintended consequence. This 'loophole' had facilitated the development of so-called "citizenship tourism": women coming to Ireland solely for the purposes of giving birth to a child who would then be entitled to Irish citizenship. In this way, particular groups of pregnant women were charged with exploiting Ireland's constitutional guarantees for citizenship; and mobile pregnant women in particular were constructed as a threat to the state. Garner (2005), Luibhéid (2004) and Lentin (2004, 2005), among others, have shown the momentum and power of this discursive construction of problem women and problem pregnancies. As Lentin argues:

the debate posits 'non-national' women as intentionally mothering the next generation of Irish citizens, illustrating not only the moral panic about 'floods of refugees' but also the insidious positioning of sexually active Irish and 'non-national' women alike as a danger to themselves, to men, and to the 'nation' (Lentin, 2004, 308).

As Lentin highlights, the discursive construction of (particular) pregnant women as incapable of caring for themselves was a recurring theme. Ireland has a long history of the denial of the rights of (particular) pregnant women: encouraging their emigration (Earner-Byrne, 2004; Ryan, 2002), their incarceration (Lentin, 2004; Ferriter, 2004), their deportation (Luibhéid, 2006), or the forced 'adoption' of their children (Ferriter, 2004, p.515) as in their better interests. This continued in the run-up to the Citizenship Referendum: Minister Michael McDowell described citizenship tourist women as "putting themselves at risk (or being put under pressure by their partners or others to take that risk) by undertaking hazardous journeys," (McDowell, 2004, p. 2) while Declan Keane, Master of Holles Street (National Maternity Hospital $)^{6}$, commented in a radio interview that:

when these women are arriving late from Nigeria ... and often arriving, as I say, unwell, with no idea of when their first menstrual period was, no idea of their dates, some of them with complex medical disorders ... Some issues we can't [deal with] (RTÉ Radio, 2003).

The Referendum was thus discursively constructed as in the best interests of pregnant women as it would remove the incentive for them to travel to Ireland to give birth. Its portrayal as altruistic denied its reinforcement of the legal place of women, especially pregnant women, in the Irish state. In particular, its attempts to impose restrictions on the travel of pregnant women resonate with the issues raised almost 10 years before in the political tensions and battles over women's reproductive and mobility rights - the $\mathrm{X}$ and $\mathrm{C}$ cases.

\section{'Abortion tourism' and the right to travel}

Abortion is not legal in Ireland, and its illegality was made explicit in a 1983 amendment to the Constitution in which the State expressly acknowledges "the right to life of the unborn and, with due regard to the equal right to life of the mother, guarantees in its laws to respect, and, as far as practicable, by its laws to defend and vindicate that right" (Bunreacht na hEireann Article 40.3.3). Despite this, many Irish women travel to Britain each year to avail themselves of legal abortion services. Numbers are difficult to quantify for a range of reasons, but possibly reach around 6,000 per annum (Oaks, 2002, p. 322). The 1983 amendment was intended to ensure that abortion would not become legal in Ireland, thus ending or silencing debate on the issue, but it has led instead to renewed debate and constitutional activity. In total there have been five constitutional referenda on abortion in Ireland in the period from 1983 to 2002 (Mullally, 2005). Since 1983, abortion has never strayed far from the political agenda in Ireland, and the public debates that surrounded the ' $\mathrm{X}$ ' case in 1992 and the ' $C$ ' case in 1997 highlight the ways in which the bodies of young women have become sites of conflict over the broader meanings of family, state and the law.

\section{The ' $\mathrm{X}$ ' case}

The ' $\mathrm{X}$ ' case involved a 14 year old girl who became pregnant as a consequence of rape. She and her parents decided to travel to England so she could have an abortion but, before travelling, they asked the Garda Síochána (Irish police force) if they should obtain any evidence from the foetus. The police referred the question to the Director of Public Prosecutions who in turn referred it to the Attorney General. The Attorney General issued an injunction to prohibit the girl and her parents from travelling to England to procure an abortion. The High Court upheld the injunction and Justice Costello, in that Court, stated that he was satisfied that there was a "real and imminent danger to the life of the unborn" (A.G. v X, 1992, Para. 19). While there was a risk that the girl may take her own life, it was "much less and of a different order of magnitude than the certainty that the life of the unborn will be terminated", thus the court's duty was to protect the life of the unborn - particularly since the "young girl has the benefit of the love and care of support of devoted parents who will help her through the difficult months ahead" (A.G. v X, 1992, Para. 19). This decision was appealed to the Supreme Court in 1992. The Supreme Court overturned this decision in a majority ruling, and Chief Justice Finlay asserted that the proper test to be applied was whether or not there was a "real and substantial risk to the life, as distinct from the health, of the mother" (A.G. v X, 1992, Para. 37). Despite this conclusion, which ultimately meant that ' $\mathrm{X}$ ' was free to travel to England for an abortion, Chief Justice Finlay also pointed out that "if there were a stark conflict between the right of a mother of an unborn child to travel and the right to life of the unborn child, the right to life would necessarily have to take precedence 
over the right to travel" (A.G. v X, 1992, Para. 53). Justice Egan concurred, arguing that the right to travel "must surely rank lower than the right to life of the unborn" (A.G. v X, 1992, Para. 185 ), and Justice Hederman in agreement argued that the preservation of life was paramount to the right to travel. Justices McCarthy and O'Flaherty expressed dissenting views on the right to travel. Justice McCarthy argued that an individual's right to travel could not be curtailed "because of a particular intent" (A.G. v X, 1992, Para. 153) while Justice O'Flaherty argued that the Court should not "interfere to this extraordinary degree with the individual's freedom of movement" (A.G. v X, 1992, Para. 166). Justice O'Flaherty further argued that the injunction represented "an unwarranted interference with the authority of the family" (A.G. v X, 1992, Para. 166).

In common with the $\mathrm{L} \& \mathrm{O}$ case over 10 years later, the judgements in the $\mathrm{X}$ case outlined differing views of the family. For Justice O'Flaherty, family authority - at least that of a heterosexual, nuclear family - was central and needed to be upheld. For Chief Justice Finlay, the unborn life could not just be seen as the responsibility of the family: in this way, the State had authority over the family in the interests of preserving life. In the context of this article, however, it is the divergences in the descriptions of $\mathrm{X}$ that are of most interest. Alternately described as a young girl, a girl, a mother, or a girl/ mother, her identity changes in line with the changing legal arguments about the relationship between the state, the family and unborn children. Take, for example, Chief Justice Finlay's argument that the right to life would have to take precedence, at times, over the right to travel. In this instance, the identity of the pregnant girl is subsumed under the category 'mother', and as a 'mother', her rights are subsumed under those of her unborn child. In fact, it is this move from girl to mother that fundamentally changes X's relationship with the State. The existence of an unborn child meant that the State could prioritise the identity of the girl as mother, and thus minimize the rights of the girl as citizen. The existence of an unborn child meant that the State could prioritise the potential family over the existing family, and insist on its rights over both.

The $\mathrm{X}$ case led to a political crisis in Ireland and, as a consequence, the Irish electorate voted again on a series of abortion-related amendments to the Constitution. In November 1992, the Irish electorate voted to accept the Thirteenth and Fourteenth Amendments to the Constitution, which guaranteed, respectively, the right to travel and the right to information. The electorate rejected the Twelfth Amendment, which drew on the Supreme Court judgement to suggest the following addition to the Constitution:

It shall be unlawful to terminate the life of an unborn unless such termination is necessary to save the life, as distinct from the health, of the mother where there is an illness or disorder of the mother giving rise to a real and substantial risk to her life, not being a risk of selfdestruction.

As a consequence of this vote, the Government stated that it would revise legislation in line with the result and with the X judgement. A Green Paper was published in 1999, but no legislation has yet been introduced.

\section{The 'C' case}

Despite the issues raised by the $\mathrm{X}$ judgement and the subsequent referendums, the issue of abortion and travel came to the forefront again in the ' $C$ ' case in 1997. As in the ' $X$ ' case, the ' $C$ ' case involved a 13 year old girl, who also was pregnant as a result of rape, and who wanted to travel to England for an abortion. After the rape, the girl was taken into the care of the Eastern Health Board, who housed her with a foster mother and who sought permission for her to travel out of Ireland for the purposes of terminating the pregnancy. Initially C's parents supported her wish for an abortion, but they later changed their minds. They appealed to the High Court a District Court decision that their daughter be allowed to leave Ireland. In particular, they claimed that the constitutional authority of the family had not been adequately recognised, and their rights and duties as parents of $C$ had not been duly considered. Justice Geoghegan, in refusing the parents' appeal, stated that they had no constitutional rights in relation to their grandchild, and implied that their rights as parents had been compromised by their behaviour. He asserted that the District Court judge was correct to take the view that C's parents were neglectful, and further commented that their behaviour "did not correspond in various respects to the kind of behaviour one would expect of parents in such appalling circumstances" (A and B, 1997, Para. 7). Justice Geoghegan concluded that he was not satisfied that, for C's parents, "their daughter's welfare is the most important consideration for them" (A and B, 1997, Para. 19). Yet the words of C's father as quoted by Justice Geoghegan present a different picture. Asked by the judge in the District Court if he had listened to the evidence of the psychiatrist, $C$ 's father said:

I did and I accept quite a lot of [his] evidence....he seemed to be a very educated man. I took a lot of it in and I know what he is talking about. The little girl herself is talking suicidal and I know if she says something it is more likely that there is a danger that she will do it....She is headstrong, but at the same time if we can avoid an abortion, if she is counselled a bit more and given a little bit more help let her have the baby if she can have it and if not then go for the abortion (A and B, 1997, Para. 21).

Though the basic facts of the $\mathrm{X}$ and $\mathrm{C}$ cases are similar both young girls, both pregnant as a result of rape, and neither wishing to go through pregnancy - the legal responses to the cases were quite different. In the $\mathrm{X}$ case, the weight of the State apparatus was brought to bear to prevent $X$ from travelling to Britain for an abortion, while 5 years later, the State sought to facilitate $C$ in her attempts to have an abortion. The intervening referendums made no substantial change to the Supreme Court judgement in the X case, which ultimately facilitated abortion in another jurisdiction provided there was a real risk to the life of a mother. The fundamental difference in the two cases related to the legal representation of the family. In the X case, judges in both the High Court and the Supreme Court commented on the exceptional qualities of X's family. In the $C$ case, the judge in the High Court supported the District Court's assessment of her parents as neglectful, and dismissed their claims that their rights and duties as parents were not adequately considered. The implication is 
that because of their neglect, their claims in respect of their daughter were invalid. Justice Geoghegan insisted that the welfare of the child (C) was "the first and paramount consideration" (A and B, 1997, Para. 17): in this manner, he authorised the courts rather than the parents as determinants of C's best interests.

These unstable and contradictory readings of the place of a young pregnant girl in the space of the family within the State take on greater significance when the $\mathrm{X}$ and $\mathrm{C}$ families are considered in more detail. The $\mathrm{X}$ family was white, suburban and middle-class (Oaks, 2002; Smyth, 1998), while C came from a Traveller family. This was made clear in court judgements: details of the $\mathrm{X}$ family were obscured, while Justice Geoghegan in the $\mathrm{C}$ case commented that C:

...is a member of the travelling community and one of a family of twelve. The evidence before the District Court is that she lived in particularly squalid conditions which were unlike the conditions in which most travelling people lived (A and B, 1997, Para. 7).

Despite the apparent sensitiveness in this statement to distinguishing "most" Travellers from this particular family, it may also be read as distinguishing Travellers from others, and to reaffirm the position of difference that Travellers occupy in Irish society. Laury Oaks, in her analysis of media and other representations of the $C$ case, highlights their (often implicit) articulation of "widespread Irish 'endogenous racism”" directed against Travellers (Oaks, 2002, p.319. See also Lentin and McVeigh, 2002; MacLaughlin, 1999). Legislative practices directed against Travellers reflect, in many instances, this form of racism, with ongoing attempts to settle Travellers, to control their movement, and to criminalize their ways of life (Crowley, 2006). The formal construction of Traveller families is relevant in this regard. The Report of the Commission on Itineracy in 1963 distinguished Traveller families from "normal" families (quoted in Crowley, 2006, p.136), and subsequent official reports commented on related topics such as the need to reduce the size of Traveller families. In other words, just as in the Fajujonu case, the 'family' is constructed through legal discourses that construct hierarchies of families. Those hierarchies, in turn, regulate access to rights within the context of the ongoing legal rescripting of the Irish state.

The legal arguments and rulings in the $\mathrm{X}$ and $\mathrm{C}$ cases are thus simultaneously the same as and different to Fajujonu and the $\mathrm{L}$ and $\mathrm{O}$ cases. Like $\mathrm{L}$ and $\mathrm{O}$ and Fajujonu, the $\mathrm{X}$ and $\mathrm{C}$ cases were built upon particular representations of the family and its relationship to the State. In particular, the discursive construction of a hierarchy of families helped determine the access $\mathrm{X}$ and $\mathrm{C}$ had to their mobility rights. However unlike $\mathrm{L}$ and $\mathrm{O}$ and Fajujonu, in the $\mathrm{X}$ and $\mathrm{C}$ cases the gendering of the pregnant girl/woman/child played a fundamental role in the different interpretations and rulings on $\mathrm{X}$ and C's social, political and civil rights. Just as Article 41 of the Irish constitution highlighted the special place of the Family within the Irish state, it also insisted on the special place of 'Woman' within the Family. Article 41.2 asserted that "by her life within the home, woman gives to the State a support without which the common good cannot be achieved. The State shall, therefore, endeavour to ensure that mothers shall not be obliged by economic necessity to engage in labour to the neglect of their duties in the home". In this way, the legal relationships between women, the family and the Irish state were codified. Discursively produced as fundamental to the workings and continuation of the Irish State, particular women have thus been subject to significant controls by the State. These controls have been varied, covering bodies (for example, limited access to contraception), labour (for example, the 'marriage ban' prevented most married women from working in public service occupations), capital (for example, inheritance law) and, importantly, women's mobility. For the most part the struggles over abortion in Ireland have been played out in attempts to regulate and control pregnant women's mobility across Ireland's international borders.

All this is important because while the legal arguments and debates presented in the Fanjujonu, L and O, X and C cases may have the aura of fixity and permanence, our discussions and arguments reveal how these are based upon mutable and changing constructions and conceptualisations of the relationship between identity and space. Legal texts and rulings like the Supreme Court rulings are part of a range of different discursive representations that imagine the nation and are always shaped in order to conform to hegemonic and dominant ideologies (Kobayashi, 1995; Young, 1997; Luibhéid, 2004). To put it another way it is mistaken to view law as simply made up of rules, regulations and procedures. These may be part of law, but law is also "a way in which a people interprets a culture to itself, a way in which a society sums up its ideals while at the same time reinforcing them...a country's laws (like its music, art, religion, history and science) is part of the story we are constantly inventing and re-inventing about who we are, where we come from and what we want to become" (Glendon, 1986: quoted in Duncan, 1988, p.75).Recognising this involves taking part in this invention and reinvention and seeking to explore ways which critical arguments may be employed to articulate an alternative politics of citizenship in Ireland. In the following section we provide some pointers to such an argument.

\section{Critical geographies of citizenship}

In our examination of the changing conceptualization of citizenship in Ireland, we have argued that legal discourses that attempt to define and fix citizenship do so through an articulation of a particular understanding of the relationship between space and identity. Certain spaces and identities are central to the process: in Ireland, ongoing contestations over the meanings and relationships between the State, the Family and Woman are crucial to understanding the articulation of citizenship. In this section of the paper, we argue that attempts to define and fix citizenship through legal discourses may be also challenged using insights from critical geographies. Our particular focus is on law, scale and mobility concepts that simultaneously work to define and challenge citizenship.

The first point of challenge comes from critical legal geography. This builds on 'critical legal studies', which examines the ways laws and legal discourses are constitutive of social life, experiences and relations. Over the last twenty years a number of geographers and legal scholars have advanced arguments and accounts that explore the mutual 
constitution of the legal, the social and the spatial (Blomley, 1994; Blomley, Delaney, and Ford, 2001; Clark, 1989; Cooper, 1998; Delaney, 1998, 2004; Ford, 1994; Kobayashi, 1995; White, 2001, 2002). Law is implicated in everyday social contexts and political struggles and these take place and are articulated over space in concrete social and political contexts. ). Theoretically, these critical legal geographers have argued for a conceptual framework that represents the world as simultaneously legal and sociospatial (Blomley quoted in Delaney, 2004, p.859).

As a way of exploring these processes Delaney (2004) uses the 'nomosphere' as a way of thinking about how spatiolegal representations overlap with the spatiolegal material world. For Delaney (2004) the nomosphere exists in the ever-shifting interplay between legal signifiers and material locations as these are mediated by sociospatial forms (Delaney, 2004, p.851). Through looking at a series of rulings over evictions from public housing programmes in the United States Delaney argues that the legal arguments made by diverse legal actors are:

ways of making sense of power and experience and meanings and the segmented spaces and places of the sociomaterial world. They are practical interventions and perturbations in the nomosphere connecting chains of signification to places and disconnecting lives from places by discursively operating on the rights and duties that are understood as binding us to our lifeworlds (Delaney, 2004 , p. 858 ).

Thus the legal arguments, representations, debates and discourses discussed in this paper are examples of such 'interventions' and 'perturbations' in the 'nomosphere' in contemporary Ireland. Our particular focus is gendered spaces: the nation, the state, the family, and the bodies of pregnant women, a focus that is often missing or marginalized in critical legal geographies. Debates about the right to family life, jus soli vs. jus sanguine, women's reproductive rights and the right to travel and information, 'citizenship tourists' and 'abortion tourists' all act to connect people to particular meaning-filled places - the home, the private sphere, maternity wards in Irish hospitals, UK abortion clinics. Equally, they also act to disconnect people from other meaning-filled places - deportees from family members and local communities, mothers-to-be from maternity services, pregnant Irish women from friends and family - in myriad ways. Similarly, the legal debates and arguments discussed in this article exist solely in the elite spaces of the courtroom and legislature, academic legal texts and dry constitutional debate. However, they are also materialized in the airlines chartered (at taxpayers' expense) to fly deportees back to their countries of origin (O'Neill, 2006), in the homes and houses hiding small children from Immigration Authorities (Corcoran \& Sheehan, 2005), in empty desks in primary and secondary schools across Ireland (Lally \& Roche, 2005), and in the inability of unemployed or low wage earning Irish women or undocumented immigrants to pay for, travel to and stay in clinics in order to have terminations in the United Kingdom (Mullally, 2005).

Thus, the range of sites in Ireland through which the moral geographies of citizenship (Cresswell, 2006) are played out is extensive. The concept of the nomosphere allows us to interrogate these sites as material locations, whose relationships with legal signifiers "are mediated by sociospatial forms, especially territories" (Delaney, 2004, p.851). However, the prioritization of territory as a sociospatial form creates its own difficulties in relation to a critical analysis of these moral geographies. It suggests that the ontological foundation of the nomosphere is based on territories held in a hierarchical relationship. Such a hierarchical relationship accords greater significance to processes that are more spatially extensive (e.g. globalization, citizenship) than to processes that are individualized or local. In the Irish case study, such a spatial hierarchy is evident in the prioritization of the State over individual women or over specific families. In this way, legal discourses construct scales of meaning and importance - scales that are unwittingly reinforced through the concept of the nomosphere. Recent scholarship within critical geography has questioned the politics of such a scalar hierarchy, and this insight represents the second point of challenge. Marston, Jones, and Woodward (2005) offer an offer an account of a human geography without scale that is based, they argue, on a flat ontology. This represents the second point of challenge. A flat ontology is based upon/ around 'sites' that emerge out of specific 'event relations'. In other words, social sites are shaped and formed through a 'neighbourhood' of practices, events and orders that are folded variously into other unfolding sites:

Neighbourhoods are not discrete, permanent and linked 'locales' but the localized expressions of endo-events and exo-events, the 'inside-of' and 'outside-of' force relations that continuously enfold the social sites they compose (Marston et al., 2005. 426).

This offers us a useful way in which to think about how Irish citizenship is put into practice through a variety of social sites including UK abortion clinics; NGO, minority community group and refugee/migrant advocacy group premises; schools; Health Board offices; media outlets; academic departments; and the Department of Justice, Equality and Law Reform; and not just through legal discourses. Thinking through the relations between these various sites "horizontally' might allow the possibility for progressive political action, as Marston et al argue:

horizontality provides more entry points - conceived as both open multi-directionally and unfolding non-linearly for progressive politics, offering the possibility of enhanced connections across sites (Marston et al., 2005, 427).

A flat ontology of scale thus challenges the assumed spatial hierarchies that underpin legal discourses around the relationship between space and identity. It highlights the interconnectedness of legal decisions that attempt to enforce state boundaries and the experiences of everyday life. Similarly, a flat ontology of scale recognizes that restrictive constructions of citizenship may be successfully challenged through everyday practices, either formally or informally. In these ways, critical geographies of scale insist on the importance of understanding the spatial imaginaries at work in the construction of legal discourses of citizenship, and on the importance of understanding the ways in which 
these discourses may be contested and overturned at a variety of different, though connected, sites and spaces.

The third point of challenge relates to mobility, which is central to many of the struggles we have outlined over citizenship in Ireland. Legal discourses of citizenship seek to fix the relationship between space and identity through defining who belongs, and who is excluded from, full participation in citizenship. Mobility - of people and of ideas - threatens that fixity, and leads to other, and more circumscribed, attempts to refix the relationship. We see this at work in the context of Ireland, where mobile women and mobile pregnant women are, at various times, constructed as a threat to the integrity and sovereignty of Ireland. This process represents State monopolization of the legitimate means of movement (Torpey, in Cresswell, 2006, p.179). In each of the Irish cases outlined above, institutions of the state were intimately involved in attempting to prevent mobility or in attempting to enforce mobility. ${ }^{7}$ Cresswell (2006), drawing on the work of Isin, argues that othering rather than exclusion is the fundamental process at work in the construction of citizenship. However, this argument minimizes the ways in which citizenship is reinforced through various practices of exclusion - from the denial of entry into a state, to deportation from the territory of a state, to the denial of permission to leave the state.

The desire to control and restrict mobility is pervasive. We have focused on mobility in relation to legal discourses around citizenship, but our argument has significantly broader import. The perceived threat posed by mobile subjects takes on a particular resonance in the context of migration. In the context of Ireland, the attempts to control or regulate the mobility of particular groups of citizens, particularly women, have been transposed onto other groups, specifically migrants. Pregnant mobile Irish women have been joined by other pregnant mobile women in the articulation of threats to the State and the justification of processes of exclusion. Migrant women and men have been variously constructed as involved in illegally mobile activities. These include activities that take place across international borders, such as people trafficking or drug smuggling, as well as activities that take place inside national borders, such as traffic offences. Just as mobile bodies are constructed as threats, there is a slippery quality to the articulation of embodied threats. As patterns of migration to Ireland change, different groups become the object of fear: from asylum seekers and 'Nigerians', to economic migrants and 'Romanians'.

However, just as we have highlighted the ways in which law and scale may be used for more progressive analyses of the construction and maintenance of citizenship, we want to argue that mobility has similarly progressive possibilities. On one level, Irish women continue to travel outside the country to avail themselves of abortion services elsewhere, most usually England and Wales. Their right to do so is constitutionally guaranteed. The Irish Family Planning Association estimates that each year, over 6,000 women from Ireland have abortions in Britain, and calculate that over $7 \%$ of abortions in England and Wales each year are performed on women with addresses in Ireland (IFPA, 2006). As Justice McCarthy pointed out in his judgement in the X case in 1992, "since the enactment of the Amendment, many thousands of Irish women have chosen to travel to England to have abortions"
(A.G. v X, 1992, Para. 154). This suggests the agency of individual women when faced with attempted restrictions on their behaviour and their mobility, though this comes at a financial and emotional cost. On another level, the discursive construction of mobility as a right - in legal judgements and in constitutional amendments - has given particular women a means to challenge and expand their rights as citizens or as potential citizens. On yet another level, despite recent changes to citizenship and to immigration law, migrants continue to travel to Ireland, in search of refuge, work and/or adventure. Their mobility and their presence in the country continues to pose challenges to attempts to fix the relationship between identity and space through legal discourse. In particular, their presence forces us to move citizenship beyond legal discourse and into everyday practices in everyday sites and spaces. It is in these everyday sites and spaces - the classroom, the shopping centre, the hospital and the home - that the meaning of citizenship and belonging is being contested on a daily basis. A progressive politics of citizenship is not, however, an inevitable consequence of mobility. Rather, as Tim Cresswell has so convincingly shown, mobility through increased levels of migration often leads to a reactionary politics of citizenship, as was the case in the US in the early twentieth century (Cresswell, 2006). Instead, the important lesson from this article is that the tools of critical geography in particular, a heightened sensitivity to the spaces of legal discourse, scale and mobility - allow us to identify the ways in which states work to fix citizenship through the articulation of specific understandings of the relationship between space and identity, and allow us to challenge those efforts.

Just as citizenship is put into practice through the articulation and enforcement of exclusion, it is imagined through its opposite, non-citizenship. What we have shown in this article is that the creation of hierarchies of citizens - women, pregnant women, travellers, heterosexual family units, middle-class families - creates a precedent that may then applied in changing contexts. In Ireland, that changing context relates to migration. As the number of asylum applications increased, the figure of the 'non-national' pregnant woman was used to signify threats to Ireland, its sovereignty and its integrity, and used as a justification for changing the definition of citizenship. Now, as new migrants arrive in Ireland, their 'non'-ness is used to rearticulate an essentialist understanding of Irish citizenship, with calls for tests for potential citizens (see Holland, 2007). In this paper, we have challenged the seeming inevitability of such attempts at fixity. We have shown how legal discourses of citizenship rely on seemingly fixed but always changeable articulations of the relationship between space and identity, and that contemporary attempts at bounding and exclusion are rooted in historical practices that create hierarchies of belonging. We have also shown how mobility disrupts fixity, and how an attention to scale focuses on connections rather than implicit hierarchies. In this way, we argue that citizenship may be reconceptualised as negotiated in everyday sites, spaces and practices - the 'nomosphere' of critical legal geography. Legal discourses attempt to create hierarchies of these spaces and their relationship with identity, but an attention to mobility and scale challenges these hierarchies and opens up citizenship to a broader, more progressive articulations that, in turn, may also change. In this way, the example of Ireland provides insights that have broader relevance, while also challenging the silences 
about the relationship between space and identity that Maighread Medbh so compellingly outlines.

\section{Endnotes}

${ }^{1}$ We recognize the difficulties with this terminology, but use it because it has become commonplace in Irish public discourses about migration. The discursive denial of nationality to certain immigrants in many ways strengthens our argument about geographic distinctions.

${ }^{2}$ Technically speaking the Department of Justice (who bear responsible for all immigration matters in Ireland) did not attempt to deport the Fajujonu parents. Instead they were denied permission to stay in the country and requested to make arrangements to leave (Breen, 2003 footnote 103).

${ }^{3}$ The Refugee Applications Commissioner commented that having Irishborn children was the biggest reason why people withdrew from the asylum process (often on the advice of staff from the Department of Justice) (NCCRI, 2004)

${ }^{4}$ This logic effectively argues that the existence of human, social and civil rights are conditional on the rights holder being capable of exercising such rights. Not only is this based on alarming logic (as Breen, 2003 argues) it is also based in 'adultist' thinking that discriminates against children.

${ }^{5}$ In his ruling, Justice Keane referred to the "difficulty of integrating people from very different ethnic and cultural backgrounds into the fabric of Irish society" (Lobe, 2003, para 56 ).

${ }^{6}$ Holles Street, in Dublin, is the National Maternity Hospital of Ireland. The Master is in administrative and clinical charge of the hospital.

${ }^{7}$ This pattern was repeated in the 2007 case of Ms D, a pregnant teenager who expressed a wish to terminate the pregnancy on being told that her baby had anencephaly, a fatal condition. The Health Services Executive instructed the Passport Office not to issue Ms D with a passport, and instructed the Irish police to arrest her if she tried to leave the country.

\section{References}

A. and B. v. Eastern Health Board. (1997). IEHC 176; [1998] 1 IR 464; [1998] 1 ILRM 460 (28th November, 1997), URL: http://www.bailii.org/ie/cases/ IEHC/1997/176.html <accessed 10/10/2006>

Anthias, Flora, \& Yuval-Davis, Nira (Eds.). (1989). Woman - Nation - State London: Macmillan.

Attorney General v. X. (1992). IESC 1; [1992] 1 IR 1 (5th March, 1992) URL: http://www.bailii.org/ie/cases/IESC/1992/1.html <accessed 10/10/2006>.

Blomley, Nicholas (1994). Law, space and the geographies of power. London: Guilford Press.

Blomley, Nicholas, Delaney, David, \& Ford, Richard T (2001). The Legal Geographies Reader. Oxford: Blackwell.

Breen, Claire (2003). Refugee Law in Ireland: Disregarding the Rights of the Child-Citizen, Discriminating Against the Rights of the Child. International Journal of Refugee Law, 15(4), 750-785

Brennoch, Mark (2004, 14 June). Fianna Fail suffers worst election results since 1920s. Irish Times, 1.

Bunreacht na hÉireann. Government Stationary Office: Dublin.

Clark, Gordon (1989). Law and the Interpretative Turn in the Social Sciences. Urban Geography, 10(3), 209-228.

Connolly, Linda (2003). The Irish women's movement: From revolution to devolution. Dublin: Lilliput.

Connolly, Linda, \& O'Toole, Tina (2005). Documenting Irish Feminisms. Dublin: Woodfield Press.

Cooper, Davina (1998). Governing out of Order: Space, Law and the Politics of Belonging. London: River Oram Press.

Corcoran, Jody, \& Sheehan, Maeve (2005, 27 March). McDowell's warning on abuse of race. Sunday Independent.

Cresswell, Tim (2006). On the move: mobility in the Modern Western World. London: Routledge.

Crowley, Úna (2006). Liberal rule through non-liberal means: The attempted settlement of Irish Travellers (1955-1975). Irish Geography, 38(2), 128-150.

Crowley, Úna, Gilmartin, Mary and Kitchin, Rob. (2008). Race and immigration in contemporary Ireland. In Claire Dwyer and Caroline Bressey (Eds.), New geographies of race and racism. Aldershot: Ashgate (pp. 141-156).

Cullen-Owens, Rosemary (2005). A social history of women in Ireland, 1870-1970. Dublin: Gill \& Macmillan.

Delaney, David (1998). Race, Place and the Law 1836 -1948. Austin: University of Texas Press.

Delaney, David (2004). Tracing displacements: Or evictions in the nomosphere. Environment and Planning D: Society and Space, 22, 847-860.
Duncan, William (1988). The Divorce Referendum in the Republic of Ireland: Resisting the Tide. International Journal of Law and the Family, 2, 62-75.

Earner-Byrne, Lindsey (2004). 'Moral repatriation': The response to Irish unmarried mothers in Britain, 1920s-1960s. In Patrick J. Duffy (Ed.), To and from Ireland: Planned Migration Schemes c.1600-2000 (pp. 155-173). Dublin: Geography Publications.

Fajujonu v. Minister for Justice [1987] IEHC 2; [1990] 2 IR 151 (11th November, 1987) URL: http://www.bailii.org/ie/cases/IEHC/1987/2.html $<$ accessed 03/10/2006>

Ferriter, Diarmaid (2004). The Transformation of Ireland 1900-2000. London: Profile.

Fletcher, Ruth (2005). Reproducing Irishness: Race, Gender, and Abortion Law. Canadian Journal of Women and the Law, 17(2), 365-404.

Ford, Richard Thompson (1994). The Boundaries of Race: Political Geography in Legal Analysis. Harvard Law Review, 107(8), 1841-1922.

Garner, Steve (2005). Guests of the Nation. Irish Review, 33, 78-84.

Garner, Steve (2007). Ireland and immigration: Explaining the absence of the far right. Patterns of Prejudice, 41(2), 109-130.

Glendon, Mary Ann (1986). Irish Family Law in Comparative Perspective: Can there be a Comparative Family Law? Francis E. Moran Lecture.

Hayes, Alan, \& Urquhart, Diane (Eds.). (2004). The Irish women's history reader London: Routledge.

Holland, Kitty (2007, 29 January). Plan to detain 'high-risk' asylum seekers. Irish Times, 6.

Irish Family Planning Association (IFPA) (2006). Irish Abortion Statistics: Irish Family Planning Association. Available online at http://www.ifpa. ie/abortion/iabst.html <accessed 16/8/2006>.

Kobayashi, Audrey (1995). Challenging the National Dream: Gender Persecution and Canadian Immigration Law. In P. Fitzpatrick (Ed.), Nationalism, Racism and the Rule of Law Dartmouth: Aldershot.

Lally, Conor, \& Roche, Barry (2005, 19 October). 50 Nigerians set to be deported on special flight. Irish Times, 10

Lentin, Ronit (2003). Pregnant silence: (en)gendering Ireland's asylum space. Patterns of Prejudice, 37(3), 301-322.

Lentin, Ronit (2004). Strangers and strollers: Feminist notes on researching migrant m/others. Women's Studies International Forum, 27, 301-314.

Lentin, Ronit (2005). Black Bodies and 'Headless Hookers': Alternative Global Narratives for 21st century Ireland. Irish Review, 33, 1-12.

Lentin, Ronit, \& McVeigh, Robbie (Eds.). (2002). Racism and Antiracism in Ireland Belfast: Beyond the Pale.

Lobe v. Minister for Justice, Equality and Law Reform. (2003). IESC 3 (23 January 2003) 372. URL: http://www.bailii.org/ie/cases/IESC/2003/3. html < accessed 03/10/2006>.

Luibhéid, Eithne (2004). Childbearing against the state? Asylum seekers women in the Irish Republic. Women's Studies International Forum, 27, 335-349.

Luibhéid, Eithne (2006). Sexual regimes and migration controls: Reproducing the Irish nation-state in transnational contexts. Feminist Review, 83, 60-78.

MacLaughlin, Jim (1999). Nation-building, social closure and anti-Traveller racism in Ireland. Sociology, 33(1), 129-151.

Marston, Sallie, Jones, John Paul, \& Woodward, Keith (2005). Human geography without scale. Transactions of the Institute of British Geographers, 30(4), 416-432.

McClintock, Anne, Mufti, Aamir, \& Shohat, Ella (1997). Dangerous Liaisons: Gender, Nation \& Postcolonial Perspectives. Minneapolis: University of Minnesota.

McDowell, Michael. (2004). Proposed Citizenship Referendum. Sunday Independent. 18 April. www/inis/.gov.ie/en/inis/article. Pdf/file/ article file.pdf (Accessed 8 July 2008).

Medbh, Máighréad (1993). Easter 1991. Feminist Review, 44, 58-60.

Mullally, Siobhán (2005). Debating Reproductive Rights in Ireland Human Rights Quarterly, 27(1). (pp. 78-104).

National Consultative Committee on Racism and Interculturalism (NCCRI) (2004). International Perspectives relating to the future of Irish Born children and their Non-National Parents in Ireland. Advocacy Paper No. 2 Dublin: NCCRI

Oaks, Laury (2002). 'Abortion is part of the Irish experience, it is part of what we are': The transformation of public discourses on Irish abortion policy. Women's Studies International Forum, 25(3), 315-333.

O'Connor, Patricia (1998). Women in Contemporary Irish Society. Dublin: Institute of Public Administration.

O'Neill, Luke (2006, 10 July). Flight to deport 13 cost over €250,000. Irish Times, 4.

Referendum Commission (2004). An Reifreann um Shaoránacht Éireann/The Referendum on Irish Citizenship. Dublin: Government Stationary Office.

RTÉ Radio.(2003). The Marian Finucane Show, Broadcast on RTÉ Radio 1, 16 October.

Ryan, Louise (2002). Sexualising Emigration: Discourses of Irish female emigration in the 1930s. Women's Studies International Forum, 25(1), 51-65. 
Ryan, Louise, \& Ward, Margaret (Eds.). (2004). Irish women and nationalism: Soldiers, new women and wicked hags Dublin: Irish Academic Press.

Smyth, Ailbhe (Ed.). (1988). Feminism in Ireland London: Pergamon Press.

Smyth, Lisa (1998). Narratives of Irishness and the Problem of Abortion: The $\mathrm{X}$ Case 1992. Feminist Review, 60, 61-83.

Valiulis, Maryann, \& O'Dowd, Mary (Eds.). (1997). Women and Irish History Dublin: Wolfhound Press.

Ward, Margaret (1991). The missing sex: Putting women into Irish history. Dublin: Attic.
White, Allen (2001). Organic functionalism, 'community' and place: Refugee studies and the geographical constitution of refugee identities. Geoforum, $33,63-73$.

White, Allen (2002). Geographies of asylum: Legal knowledge and legal practices. Political Geography, 21, 1055-1073.

Young, Craig (1997). Political Representation of Geography and Place in the United Kingdom. Asylum and Immigration Bill (1995). Urban Geography, 18(1), 62-73.

Yuval-Davis, Nira (1997). Gender and Nation. London: Sage. 